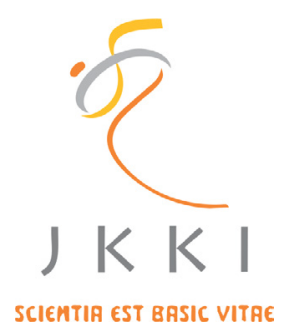

Jurnal Kedokteran dan Kesehatan Indonesia

Indonesian Journal of Medicine and Health

Journal homepage : https://journal.uii.ac.id/JKKI

\title{
The ethyl acetate fraction of sponge Stylissa carteri decreases viability in HER2 + trastuzumab-resistant breast cancer cells
}

Julia Nur Jannah ${ }^{1}$, Pandji Irani Fianza르, Tenny Putri ${ }^{3}$, Muhammad Hasan Bashari*4,5

${ }^{1}$ Medical Study Program, Faculty of Medicine, Universitas Padjajaran, Bandung, Indonesia

${ }^{2}$ Department of Internal Medicine, Hemato-Oncology Division, Hasan Sadikin Hospital, Bandung, Indonesia

${ }^{3}$ Advanced Biomedical Laboratory, Faculty of Medicine, Universitas Padjajaran, Bandung, Indonesia

${ }^{4}$ Department of Basic Medical Sciences, Division of Pharmacology and Therapy, Faculty of Medicine, Universitas

Padjajaran, Bandung, Indonesia

${ }^{5}$ Center for Oncology and Stem Cell Studies, Faculty of Medicine, Padjadjaran University, Bandung, Indonesia

Original Article

\begin{tabular}{l} 
ART ICLE INF O \\
\hline Keywords: \\
breast cancer, \\
cell viability, \\
HER2 positive, \\
marine sponge, \\
trastuzumab resistance, \\
Stylissa carteri \\
*Corresponding author: \\
bashari@unpad.ac.id \\
\hline DOI: 10.20885/JKKI.Vol10.Iss3.art6 \\
History: \\
Received: November 19, 2018 \\
Accepted: October 2, 2019 \\
Online: December 30, 2019 \\
\hline Copyright @2019 Authors. \\
This is an open access article \\
distributed under the terms \\
of the Creative Commons At- \\
tribution-NonCommercial 4.0 \\
International Licence (http:// \\
creativecommons.org/licences/ \\
by-nc/4.0/).
\end{tabular}

ABSTRACT

Background: HER2+ breast cancer is a very aggressive type of breast cancer. Although trastuzumab, specifically targeted for HER2, has been used for breast cancer treatments, some patients become resistant to trastuzumab. A marine sponge is one of the potential sources of anticancer agents. One of marine sponges commonly found in Indonesia is Stylissa carteri, but it has not been explored extensively.

Objective: This study aimed to identify cytotoxic effects of the ethyl acetate fraction of Stylissa carteri on HCC-1954, HER2+ trastuzumabresistant breast cancer cells, by assessing cell viability and determining $\mathrm{IC}_{50}$ value.

Methods: This study was an experimental in vitro study conducted in The Cell Culture Laboratory, Faculty of Medicine Universitas Padjadjaran on February 2018 to June 2018. The Stylissa carteri was collected from Pramuka Island, Kepulauan Seribu National Park Jakarta. HCC-1954 cells were treated by serial concentration of fractions and were incubated for 72 hours. Cell viability were observed under a microscope and analysed with MTT assay. The $\mathrm{IC}_{50}$ value was also determined by using four parametric logistic regression (4PL) method by Sigmaplot version 12.0.

Result: Data of this study showed descent of cell viability significantly when exposing the ethyl acetate fraction of Stylissa carteri. There was a decrease of $49 \%$ cell viability in $10 \mu \mathrm{g} / \mathrm{ml}$ of the ethyl acetate fraction of Stylissa carteri. The estimated IC ${ }_{50}$ value was $9.25 \mu \mathrm{g} / \mathrm{ml}$.

Conclusion: This result indicated that the ethyl acetate fraction of Stylissa carteri has cytotoxic effects on HER2+ trastuzumab-resistant breast cancer cells.

Latar Belakang: Kanker payudara tipe HER2+ adalah jenis yang sangat agresif. Walaupun tersedia trastuzumab yang secara spesifik mentarget HER2, sebagian pasien mengalami resistensi terhadap trastuzumab. Spons laut diketahui berpotensi baik sebagai sumber obat anti kanker. Stylissa carteri adalah salah satu spesies spons laut yang banyak ditemukan di perairan Indonesia namun belum banyak dieksplorasi potensinya.

Tujuan: Penelitian ini bermaksud untuk mengetahui efek sitotoksik fraksi etil asetat Stylissa carteri terhadap sel kanker payudara HER2+ resisten trastuzumab (HCC-1954) melalui parameter viabilitas sel dan penghitungan nilai $I C_{50^{\circ}}$ 


\begin{abstract}
Metode: Penelitian ini adalah penelitian eksperimen in vitro yang dilakukan di Laboratorium Kultur Sel, Fakultas Kedokteran Universitas Padjadjaran pada Februari 2018 sampai Juni 2018. Bahan spons Stylissa carteri diperoleh dari perairan pulau Pramuka, kepulauan Seribu DKI Jakarta. Sel HCC1954 diberi perlakuan berupa seri konsentrasi fraksi etil asetat Stylissa carteri yang diinkubasi selama 72 jam. Sel viabel diamati dengan mikroskop dan dianalisis menggunakan uji MTT. Analisis nilai IC50 dilakukan dengan menggunakan Sigmaplot dengan metode four parametric logistic regression (4PL).

Hasil: Terdapat penurunan viabilitas sel kanker payudara HER2+ resisten trastuzumab setelah diberi fraksi etil asetat Stylissa carteri. Pada konsentrasi $10 \mu \mathrm{g} / \mathrm{ml}$ terjadi penurunan viabilitas sel sebanyak 49\%. Fraksi etil asetat Stylissa carteri memiliki IC ${ }_{50}$ sebesar 9,25 $\mu \mathrm{g} / \mathrm{ml}$.
\end{abstract}

Kesimpulan: Fraksi etil asetat Stylissa carteri memiliki efek sitotoksik terhadap sel kanker payudara tipe HER2 + resisten trastuzumab.

\section{INTRODUCTION}

The World Health Organization (WHO) stated that cancer is the second-highest cause of deaths in the world. ${ }^{1}$ Among the cancer, breast cancer is the most common cancer for women in the world with more than 1.7 million incidences. Prevalence rates of breast cancer in Indonesia are also the highest among other types of cancers. ${ }^{2}$

Breast cancer is a condition of uncontrolled growth of breast tissue. It is mainly caused by genetic mutations that induce cells to proliferate. ${ }^{3}$ Molecularly, by looking at presence of hormone receptors (estrogen or progesterone) and human epidermal growth factor receptor 2 (HER2), the breast cancer is classified into several types, namely basal-like, luminal A, luminal B, HER2 enriched, and normal-like. ${ }^{4,5}$ Amplification of HER2 may be concomitant with an increase in estrogen receptor (ER) and progesterone receptor (PR) in luminal $B$ patients or alone in HER2 enriched patients. ${ }^{6,7}$ HER2+ is one of the most aggressive types. It has a high proliferation rate and a poor prognosis. ${ }^{5,8,9}$ Activation of HER2 receptors through dimerization with HER1, 3, or 4 usually induces phosphorylation and its residue will activate various secondary messenger pathways then activate various transcription factors. This transcription factors play essential roles in cancer progression. ${ }^{8,10}$

Currently there has been available drugs that specifically can inhibit the HER2, such as trastuzumab, pertuzumab, and lapatinib. These drugs become a primary therapy for patients with HER2 and breast cancer. However, some patients with an advanced stage become resistant to these drugs. ${ }^{11}$ This conditions indicate the needs of novel drugs and therapeutic methods in particular for breast cancer patients who are resistant to HER2 inhibitor drugs, especially trastuzumab.

Marine sponges are known to produce compounds that have anti-cancer substances. Marine sponges Rhabdastrella globostellata contains isomalabaricane triterpenoids (Stelletin $\mathrm{J}$ and $\mathrm{K}$ ) and have a cytotoxic effect on ovarian cancer cells. ${ }^{12}$ Additionally, sesquiterpenoid cryptosphaerolide compounds originating from Cryptosphaeria sp. have a cytotoxic effect on colon cancer cells. ${ }^{13,14}$ The United States Food and Drug Administration (FDA) has also approved uses of eribulin mesylate for breast cancer patients who have metastasized in $2010 .^{15}$ This drug is a synthetic analog of Halichondrin $B$ compound which is an effective inhibitor of dynamic microtubules. ${ }^{16,17}$ The Halichondrin B compound is isolated from Halichondria okadai, a Japanese sea sponge. Clinical trials show that the Halichondrin B compound has a reasonably good anti-cancer effect on breast cancer that has previously been treated with conventional chemotherapy. ${ }^{18}$

Stylissa carteri is a marine sponge whose habitat spreads from the Red Sea to Australia, including Indonesia. ${ }^{19}$ There are fewer studies on Stylissa carteri as an anti-cancer. A study found that Stylissa carteri contained several groups of compounds, such as alkaloids and peptides. ${ }^{19}$ Another study showed that these groups of compounds had anti-cancer effects. ${ }^{19,20}$

The ethanol extract of Stylissa carteri has cytotoxic effects on several cancer cell lines, including luminal A, HER2 + and triple-negative type breast cancer cells, and cervical cancer cells. ${ }^{21,22}$ To further purify compounds of Stylissa 
carteri and to obtain stronger potential of anticancer fraction, this study was conducted to explore effects on fraction levels, especially on the ethyl acetate fraction. This study aimed to determine the cytotoxic effects of ethyl acetate fraction of the Stylissa carteri on trastuzumabresistance HER2+ breast cancer cells, HCC-1954 in vitro through its cytotoxicity parameters using the 3- [4,5-dimethylthiazol-2-yl] -2.5 diphenyl tetrazolium bromide (MTT) assay and estimation of $50 \%$ inhibitory concentration $\left(\mathrm{IC}_{50}\right.$ ).

\section{METHODS}

This study was an experimental research design in vitro. This study was approved by Ethics Committee of Faculty of Medicine, Padjadjaran University, number: 504/UN6.KEP/EC/ 2018. It was conducted at the Culture and Cytogenic Laboratory, Faculty of Medicine Universitas Padjadjaran, on February 2018 to June 2018.

\section{Preparation of the ethyl acetate fraction of Stylissa carteri}

The marine sponge Stylissa carteri obtained from Pramuka Island, National Park of Kepulauan Seribu, Province of Jakarta (Figure 1). A total number of 800 grams of a fresh wet sponge were chopped and macerated directly by using ethanol for a next extraction process. Through the extraction process, 10.2 grams of powder of ethanol extraction were obtained. Fractionation was conducted on 5 grams of extracted powder by using ethyl acetate solvent. Through this process, $142.3 \mathrm{mg}$ of dry powder was obtained. It was diluted with dimethylsulfoxide (DMSO) solvent for having a concentration of $40,000 \mu \mathrm{g} / \mathrm{ml}$. This solution was used as a stock solution. This solution was further diluted with the Roswell Park Memorial Institute (RPMI) medium to form fractions with concentration of 5, 10, 25, 50, 100, and $200 \mu \mathrm{g} / \mathrm{ml}$.

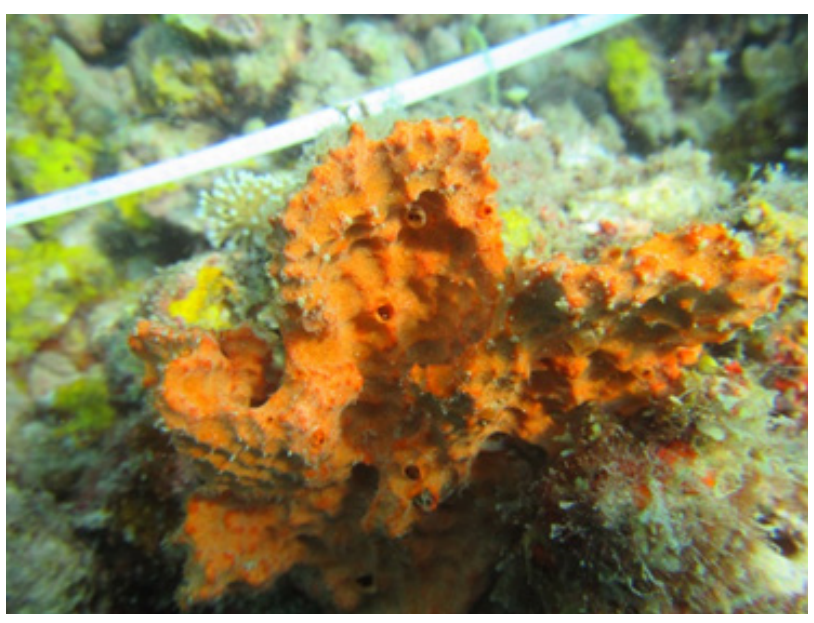

Figure 1. Marine Sponge Stylissa carteri

\section{HER2 + cell culture}

This study was conducted on the trastuzumabresistant HER2 + breast cancer cell lines, namely HCC-1954 cells obtained from the National Center for Tumor Diseases (NCT), Heidelberg, Germany. HCC-1954 cells grew in RPMI media supplemented with $10 \%$ of fetal bovine serum (FBS) and 1\% of penicillin-streptomycin. The HCC-1954 cells were cultured in incubator at $37^{\circ} \mathrm{C}$, containing $5 \%$ of carbon dioxide $\left(\mathrm{CO}_{2}\right)$ and culture cell standard humidity.
For experiments, number of 10,000 HCC1954 cells $/ 200 \mu \mathrm{L}$ were seeded in 60 inner wells in a 96 well dish. In 36 external wells, $200 \mu \mathrm{L}$ phosphate buffer saline (PBS) was added. The cells were incubated for 24 hours at $37^{\circ} \mathrm{C}$. Next, the cells were treated with a serial concentration of the ethyl acetate fraction of Stylissa carteri with concentration of $5,10,25,50,100$, and $200 \mu \mathrm{g} /$ $\mathrm{ml}$. A negative control group (the ethyl acetate fraction of Stylissa carteri with concentration of $0 \mu \mathrm{g} / \mathrm{ml}$ ) was treated as $1 \%$ DMSO in standard 
medium. All groups were incubated for 72 hours before microscopic observation and MTT assay. The experiments were conducted for triplicate times at different times.

Microscopic observations were done by using an Olympus CX1 inverted microscope that was connected to the camera. Description of differences in cell morphology due to exposure to test materials were presented descriptively.

\section{Cytotoxic test (MTT and IC $_{50}$ )}

The 3-[4,5-dimethylthiazol-2-yl] -2,5 diphenyl tetrazolium bromide (MTT) test was organized to calculate cell viability. The MTT test was initiated by replacing the growing media in each well with $100 \mu \mathrm{L}$ of MTT reagent and was incubated for 4 hours. Three empty wells adding with $100 \mu \mathrm{L}$ of MTT reagent were used as the blank wells. After the incubation period ended, in each well $100 \mathrm{ml}$ DMSO solution was added. Dissolving formed crystals was performed by shaking plates in shaker orbitals for 15 minutes. Media absorbance was measured by using a plate reader with a wavelength of $550 \mathrm{~nm}$.
All absorbances data were subtracted with absorbance of the blank wells. The percentage of viable cells was calculated by dividing sample absorbances by the negative control absorbance and multiple by one hundred percent. $\mathrm{IC}_{50}$ value was determined by using a SigmaPlot software with a 4 parametric logistic regression (4PL) method.

\section{RESULTS}

The ethyl acetate fraction of Stylissa carteri caused decreasing of viable HCC-1954 cells by microscopic images (Figure 2). The cell viability decreases with increasing doses of the ethyl acetate fraction of Stylissa carteri. In untreated cells (Figure 2a), many viable HCC-1954 cells could be seen. Viable cell images were decrease in treated groups of the ethyl acetate fraction Stylissa carteri at concentration of $5 \mu \mathrm{g} / \mathrm{ml}$ (Figure 2b). The fewest viable cells were seen in groups treated by the ethyl acetate fraction Stylissa carteri at concentration of $200 \mu \mathrm{g} / \mathrm{ml}$ (Figure 2d).

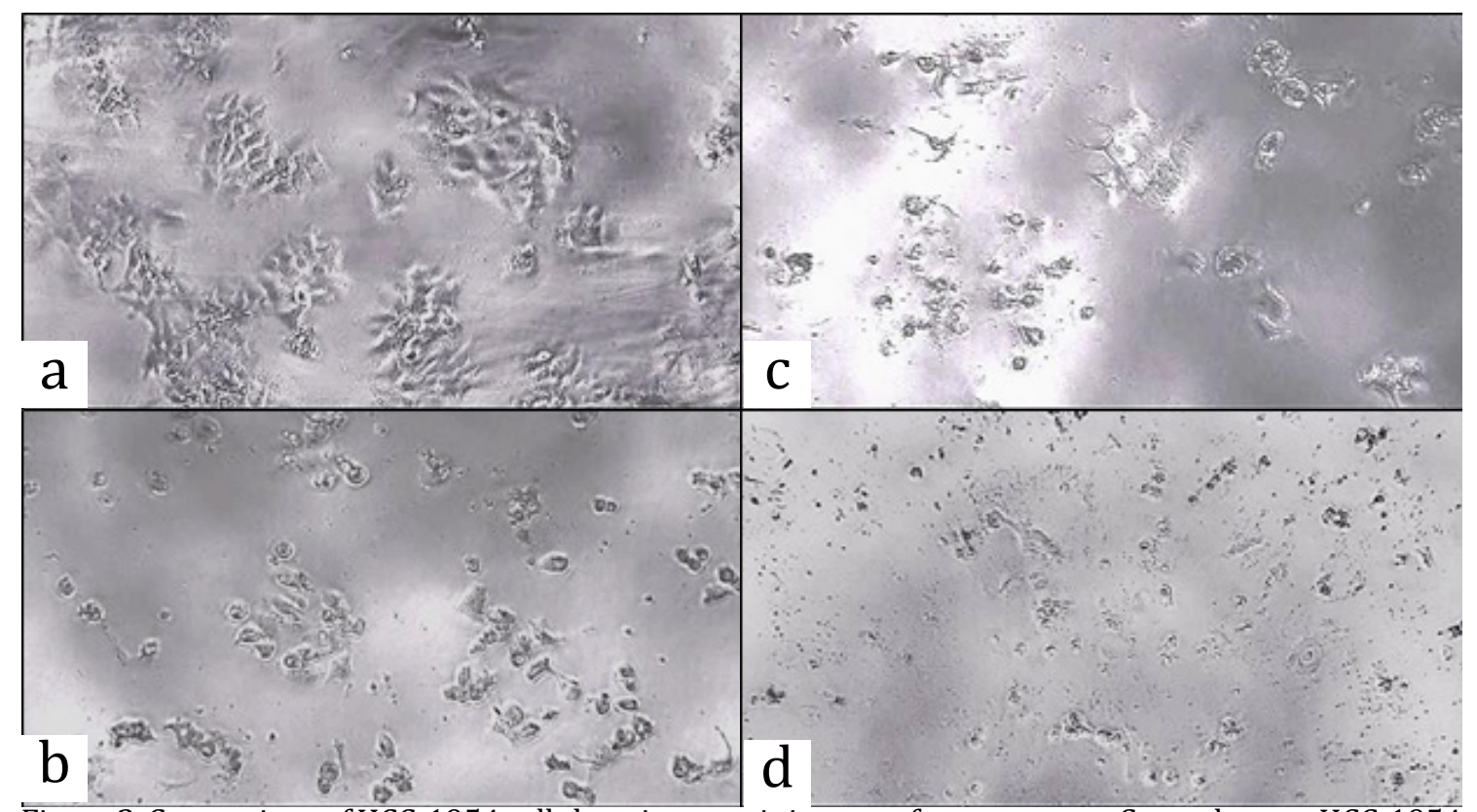

Figure 2. Comparison of HCC-1954 cells by microscopic images after treatment. Controls were HCC-1954 cells incubated with the ethyl acetate fraction of Stylissa carteri at concentration of $0 \mu \mathrm{g} / \mathrm{ml}(\mathrm{a})$. HCC1954 cells were treated with the fractions at concentration of $5 \mu \mathrm{g} / \mathrm{ml}, 10 \mu \mathrm{g} / \mathrm{ml}$ and $20 \mu \mathrm{g} / \mathrm{ml}$, showed reductions of viable cells with increased concentration of the fractions $(b, c, d)$. 
MTT tests showed that cell viability decreased with increasing concentrations of the ethyl acetate fraction of Stylissa carteri (Figure 3).
The $\mathrm{IC}_{50}$ value of the ethyl acetate fraction of Stylissa carteri was $9.25 \mu \mathrm{g} / \mathrm{ml}$ with Rsqr $=0.986$.

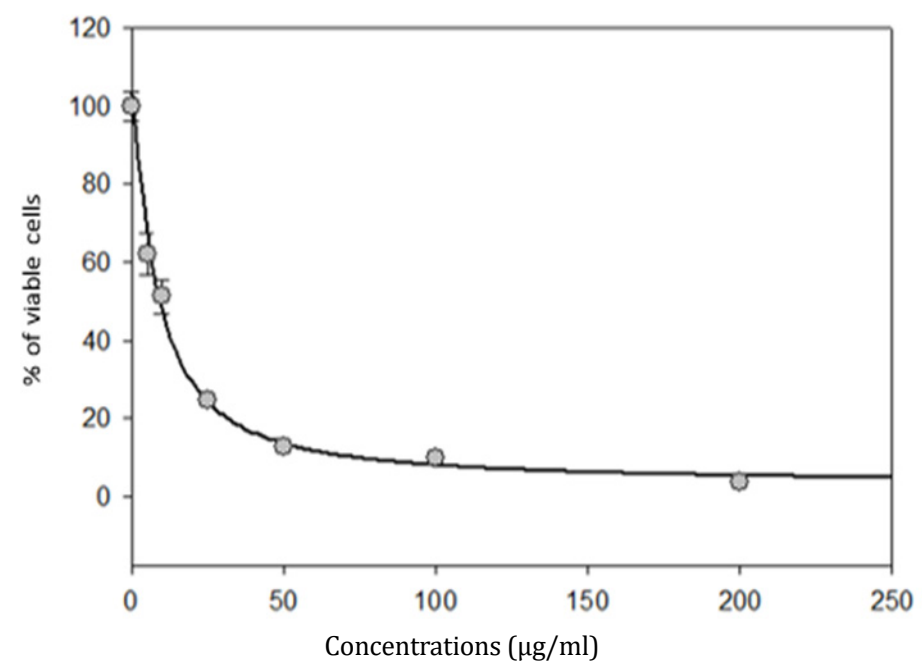

Figure 3. Curve of decreasing percentage of viable HCC-1954 cells by exposing the ethyl acetate fraction of Stylissa carteri

\section{DISCUSSIONS}

Stylissa carteri is one of marine sponges that exist in Indonesian marine. Previous studies showed that ethanol extraction of this sponge caused inhibition of proliferation and migration. ${ }^{22}$ The IC ${ }_{50}$ of the ethanol extract of Stylissa carteri in HCC-1954 cells was $14 \mu \mathrm{g} / \mathrm{ml} .^{22}$ In our study, the $\mathrm{IC}_{50}$ of the ethyl acetate fraction of Stylissa carteri was $9.25 \mu \mathrm{g} / \mathrm{ml}$. Based on these data, it could be concluded that the cytotoxic effects of the ethyl acetate fraction were stronger than the ethanol extract.

A compound could be classified as a potential cytotoxic compound if its $\mathrm{IC}_{50}$ value is less than $100 \mu \mathrm{g} / \mathrm{ml}$, moderate cytotoxic if the $\mathrm{IC}_{50}$ value are between 100 and $1000 \mu \mathrm{g} / \mathrm{ml}$, and as a noncytotoxic group if the $\mathrm{IC}_{50}$ value is more than 1000 $\mu \mathrm{g} / \mathrm{ml}^{23}$ Therefore, the ethyl acetate fraction of Stylissa carteri in this study was classified as a potential cytotoxic against HER2+ breast cancer cells.

Moreover, Stylissa carteri had also been tested on several other types of cancer cells. A previous study showed that the ethanol extract of Stylissa carteri was cytotoxic against cervical cancer cells (the $\mathrm{IC}_{50}=1 \mu \mathrm{g} / \mathrm{ml}$ ). ${ }^{21}$ The findings above indicated that Stylissa carteri consisted of active compounds that could be potentially developed into potential candidates to reduce viability of some types of cancer.

Marine sponges commonly contain cyclic peptides, alkaloids, sterols, terpenes, fatty acids, and peroxides. By presence of these compounds, the sponges have an antibacterial, antifungal, antimalarial, anthelmintic, immunosuppressive, muscle relaxant, anti-inflammatory, and anticancer effect. ${ }^{24}$ Based on chemical tests conducted by Rivai, Stylissa carteri contained many groups of alkaloids, steroids, and terpenoid compounds. ${ }^{25}$ Beside identified compounds contained in Stylissa carteri, among them were oroidin, hanishin, latonduine, stevensine, hymenin, and debromohymenin, dibromoisophakellin, and ugibohlin, carteramine $\mathrm{A}$ and hanishenol compounds. ${ }^{26}$ Of these various compounds, cyclic peptides and alkromoids had been considered to have properties of anti-cancer. ${ }^{19}$

Cyclic peptides have cytotoxic effects on cancer cells. They involved in regulating pro-apoptotic proteins such as Bax and Bak. 
Increased expression of the pro-apoptotic protein will induce apoptosis or cell death. ${ }^{20}$ More over, alkaloid compounds in the Stylissa carteri may become protein kinase inhibitors. The protein kinase played an essential role in cell proliferation. ${ }^{19}$ Therefore, if there was inhibition of the protein kinase, the cell proliferation would be disrupted.

Our data indicated that Stylissa carteri could be a source of isolation of anti-cancer compounds, especially for HER2+ cells that were resistant to trastuzumab. For this reason, further studies need to be conducted to determine molecular mechanisms that cause death of cancer cells during administration of the Stylissa carteri. Also, it is necessary to identify and isolate active compounds contained in the Stylissa carteri fraction. Therefore, hopefully a new anticancer drug can be discovered through various biodiversity in Indonesia.

\section{CONCLUSION}

The ethyl acetate fraction of Stylissa carteri was cytotoxic against trastuzumab type HER2+ resistant breast cancer cells.

\section{CONFLICT OF INTEREST}

In this study, the authors stated that there was no conflict of interest.

\section{ACKNOWLEDGEMENT}

The authors would like to thank to Beginer Subhan from Bogor Institute of Agriculture and Harold Atmaja for assisting the process of collecting marine sponge samples in Pramuka Island. The authors also thank to National Park of Kepulauan Seribu for its permission to take the marine sponge samples. The authors also thank to Nurul Qomarilla for her assistance in conducting this study. This study is part of the OCEAN Project funded by Padjadjaran University's Internal Grant with the RKDU scheme for MHB (no.2476 / UN6.C / LT / 2018).

\section{REFERENCES}

1. WHO. WHO _ Cancer [Internet]. WHO. World Health Organization; 2017. Available from: http://www.who.int/mediacentre/ factsheets/fs297/en/

2. Soediono B, Kementerian Kesehatan RI, Kementerian Kesehatan Republik Indonesia. Situasi Penyakit Kanker. 2015.

3. CDC - Breast Cancer.

4. Dai X, Li T, Bai Z, Yang Y, Liu X, Zhan J, et al. Breast cancer intrinsic subtype classification, clinical use and future trends. American Journal of Cancer Research. 2015;5(10):2929-43.

5. Eroles P, Bosch A, Alejandro Pérez-Fidalgo J, Lluch A. Molecular biology in breast cancer: Intrinsic subtypes and signaling pathways. Cancer Treatment Reviews. 2012;38(6):698-707.

6. Toss A, Cristofanilli M. Molecular characterization and targeted therapeutic approaches in breast cancer. Breast Cancer Research. 2015;17(1):60.

7. Makki J. Diversity of breast carcinoma: Histological subtypes and clinical relevance. Clinical Medicine Insights: Pathology. 2015;8:23-31.

8. Yersal 0, Barutca S. Biological subtypes of breast cancer: Prognostic and therapeutic implications. World Journal of Clinical Oncology. 2014;5(3):412-24.

9. Cho N. Molecular subtypes and imaging phenotypes of breast cancer. Ultrason (Seoul, Korea). 2016;35(4):281-8.

10. Gutierrez C, Schiff R. HER2: Biology, detection, and clinical implications. Archives of Pathology \& Laboratory Medicine. 2011;135:55-62.

11. Pohlmann PR, Mayer IA, Mernaugh R. Resistance to trastuzumab in breast cancer. Clinical Cancer Research. 2009;15(24):747991.

12. Kim SK, Li YX. Handbook of anticancer drugs from marine origin. Springer International Publishing. Switzerland. 2015; p: 1-805.

13. Schumacher M, Kelkel M, Dicato M, Diederich M. Gold from the sea: Marine compounds as inhibitors of the hallmarks of cancer. Biotechnology Advances. 2011;29(5):531-47.

14. Oh H, Jensen PR, Murphy BT, Fiorilla C, 
Sullivan JF, Ramsey T, et al. Cryptosphaerolide, a cytotoxic Mcl-1 inhibitor from a marine-derived ascomycete related to the genus Cryptosphaeria. Journal of Natural Products. 2010;73(5):998-1001.

15. U.S. Food and Drug Administration.Drugs@ FDA: FDA Approved Drug Products [Internet]. Available from: https://www.accessdata.fda.gov/scripts/cder/daf/index. cfm?event=overview.process\&amp;applno $=201532$

16. Smith JA, Wilson L, Azarenko O, Zhu X, Lewis BM, Littlefield BA, et al. Eribulin binds at microtubule ends to a single site on tubulin to suppress dynamic instability. Biochemistry. 2010;49(6):1331-7.

17. Jimeno A. Eribulin: Rediscovering tubulin as an anticancer target. Clinical Cancer Research. 2009;15(12):3903-5.

18. Cortes J, Vahdat L, Blum JL, Twelves C, Campone $\mathrm{M}$, Roché $\mathrm{H}$, et al. Phase II study of the halichondrin $\mathrm{B}$ analog eribulin mesylate in patients with locally advanced or metastatic breast cancer previously treated with an anthracycline, a taxane, and capecitabine. Journal of Clinical Oncology. 2010;28(25):3922-8.

19. Dewi AS. When east meets west: The chemistry of Indonesian sponges and Australian nudibranchs. The University of Queensland; 2017.

20. J. Boohaker R, W. Lee M, Vishnubhotla $P$, M. Perez JL, R. Khaled A. The use of therapeutic peptides to target and to kill cancer cells. Current Medicinal Chemistry. 2012;19(22):3794-804.

21. Hardani IN, Damara FA, Nugrahani AD, Bashari MH. Ethanol extract of Stylissa carteri induces cell death in parental and paclitaxel-resistant cervical cancer cells. International Journal of Integrated Health Sciences. 2018;6(2):91-6.

22. Bashari MH, Huda F, Tartila TS, Shabrina S, Putri T, Qomarilla N, et al. Bioactive compounds in the ethanol extract of marine sponge Stylissa carteri demonstrates potential anti-cancer activity in breast cancer cells. Asian Pacific Journal of Cancer Prevention. 2019;20(4):1199-206.
23. Prayong P, Barusrux S, Weerapreeyakul N. Cytotoxic activity screening of some indigenous Thai plants. Fitoterapia. 2008;79(78):598-601.

24. Hassan SS ul, Shaikh AL. Marine actinobacteria as a drug treasure house. Biomed Pharmacotherapy. 2017;87(4):46-57.

25. Rivai H, Meliyana, Handayani D. Karakterisasi ekstrak spon laut Axinella carteri dendy secara fisika, kimia dan fisikokimia. Jurnal Farmasi Higea. 2010;2(1):1-12.

26. Patel K, Laville R, Martin MT, Tilvi S, Moriou C, Gallard JF, et al. Unprecedented stylissazoles A-C from Stylissa carteri: Another dimension for marine pyrrole-2-aminoimidazole metabolite diversity. Angewandte Chemie International Edition. 2010;49(28):4775-9. 